\title{
Validating a heat stress model: The effects of an electric heat blanket and nutritional plane on lactating dairy cows
}

\author{
M. Al-Qaisi, ${ }^{1,2}$ E. J. Mayorga, ${ }^{1}$ E. A. Horst, ${ }^{1}$ S. K. Kvidera, ${ }^{1}$ C. S. McCarthy, ${ }^{1}$ M. A. Abeyta, ${ }^{1}$ B. M. Goetz, ${ }^{1}$ \\ H. A. Ramirez-Ramirez, ${ }^{1}$ L. L. Timms, ${ }^{1}$ and L. H. Baumgard ${ }^{1 *}$ \\ ${ }^{1}$ Department of Animal Science, lowa State University, Ames 50011 \\ ${ }^{2}$ Department of Animal Production, The University of Jordan, Amman, Jordan 11942
}

\begin{abstract}
The efficacy of an electric heat blanket (EHB) has previously been confirmed as an alternative method to evaluate heat stress (HS). However, a pair-feeding design has not been used with the EHB model. Therefore, study objectives were to determine the contribution of the nutritional plane to altered metabolism and productivity during EHB-induced HS. Multiparous Holstein cows $(\mathrm{n}=18 ; 140 \pm 10 \mathrm{~d}$ in milk) were subjected to 2 experimental periods (P); during P1 (4 d), cows were in thermoneutral conditions with ad libitum feed intake. During P2 $(4 \mathrm{~d})$, cows were assigned to 1 of 2 treatments: (1) thermoneutral conditions and pair-fed (PF; $\mathrm{n}=8$ ) or (2) EHB-induced HS with ad libitum feed intake $(\mathrm{n}=10)$. Overall, the EHB increased rectal temperature, vaginal temperature, skin temperature, and respiration rate $\left(1.4^{\circ} \mathrm{C}, 1.3^{\circ} \mathrm{C}, 0.8^{\circ} \mathrm{C}\right.$, and 42 breaths/ min, respectively) relative to PF cows. The EHB reduced dry matter intake (DMI; 47\%) and, by design, $\mathrm{PF}$ cows had a similar pattern and extent of decreased DMI. Milk yield decreased in EHB and PF cows by $27.3 \%(12.1 \mathrm{~kg})$ and $13.4 \%(5.4 \mathrm{~kg})$, respectively, indicating that reduced DMI accounted for only $\sim 50 \%$ of decreased milk synthesis. Milk fat content tended to increase $(19 \%)$ in the EHB group, whereas in the $\mathrm{PF}$ cows it remained similar relative to P1. During P2, milk protein and lactose contents tended to decrease or decreased (1.3 and 2.2\%, respectively) in both EHB and $\mathrm{PF}$ groups. Milk urea nitrogen remained unchanged in PF controls but increased (34.2\%) in EHB cows relative to $\mathrm{P} 1$. The EHB decreased blood partial pressure of $\mathrm{CO}_{2}$, total $\mathrm{CO}_{2}, \mathrm{HCO}_{3}$, and base excess levels (17, 16,17 , and $81 \%$, respectively) compared with those in PF cows. During P2, the EHB and PF cows had similar decreases $(4 \%)$ in plasma glucose content, but no differences in circulating insulin were detected. However, a
\end{abstract}

Received September 4, 2019.

Accepted January 27, 2020.

*Corresponding author: baumgard@iastate.edu group by day interaction was detected for plasma nonesterified fatty acids; levels progressively increased in $\mathrm{PF}$ controls but remained unaltered in the EHB cows. Blood urea nitrogen increased in the EHB cows (61\%) compared with the PF controls. In summary, utilizing the EHB model indicated that reduced nutrient intake explains only about $50 \%$ of the decrease in milk yield during HS, and the postabsorptive changes in nutrient partitioning are similar to those obtained in climatecontrolled chamber studies. Consequently, the EHB is a reasonable and economically feasible model to study environmental physiology of dairy cows.

Key words: heat stress, pair-feeding, dairy cow

\section{INTRODUCTION}

Heat stress (HS) imposes a major hurdle to efficient livestock productivity. In the US dairy industry alone, environmental hyperthermia costs more than $\$ 1.5$ billion annually (Key and Sneeringer, 2014). This financial burden is explained by reduced milk yield, impaired growth rates, decreased reproductive performance, and compromised health (Kadzere et al., 2002). Therefore, HS limits the production of high-quality dairy products for human consumption, compromises farm profitability, and is a serious food security issue (particularly in many developing countries; Baumgard and Rhoads, 2013).

During HS, dairy cows voluntarily reduce feed intake, which is presumably a key strategy to decrease metabolic heat production (Kadzere et al., 2002; West, 2003; Baumgard and Rhoads, 2013). It has traditionally been thought that reduced feed intake is responsible for decreased milk production (Fuquay, 1981; Collier et al., 1982; West, 2003). However, our previous experiments utilizing a pair-feeding design demonstrated that hypophagia explains only about $50 \%$ of the decreased milk yield during HS (Rhoads et al., 2009; Wheelock et al., 2010; Baumgard et al., 2011), indicating that HS decreases milk yield by both indirect (via reduced feed intake) and direct effects (Baumgard and Rhoads, 2012, 
2013). Independent of reduced nutrient consumption, HS directly alters postabsorptive carbohydrate, lipid, and protein metabolism, which is primarily characterized by increased circulating insulin, blunted adipose tissue mobilization, and increased plasma markers of muscle catabolism (Baumgard and Rhoads, 2013). The aforementioned changes to insulin and adipose tissue (seemingly reflective of anabolic metabolism) are bioenergetically difficult to explain because HS can be a hypercatabolic and life-threatening condition. Thus, having a better understanding of how and why HS initiates these unique alterations to nutrient partitioning is likely a prerequisite to developing effective mitigation strategies.

Accurately parsing between the direct and indirect consequences of HS traditionally required environmental chambers. This is primarily because obtaining a true thermoneutral environment in a natural setting is difficult and these studies rely on active cooling to keep the controls from becoming exceedingly hyperthermic. Further, daily variation in ambient conditions (e.g., temperature, humidity, wind, solar radiation) create inconsistent heat-loads during the experiment. However, most institutions do not have environmental chambers large enough for cattle due to construction costs and operational expenses. Thus, we developed a HS model that uses an electric heat blanket (EHB) as a costeffective way to induce HS (based upon thermal indices and production phenotypes) in dairy cows (Al-Qaisi et al., 2019). However, we have not determined whether the direct effects of EHB-induced HS alter metabolism similarly to climate-controlled experiments. Therefore, study objectives were to determine the contribution of the nutritional plane to altered metabolism and productivity in the EHB model.

\section{MATERIALS AND METHODS}

\section{Animals and Experimental Design}

All procedures were approved by the Iowa State University Institutional Animal Care and Use Committee. Eighteen lactating Holstein cows $(140 \pm 10$ DIM; $674 \pm 15 \mathrm{~kg}$ of BW; parity $2.3 \pm 0.1$ ) were housed in sand- and straw-bedded individual box stalls $(4.57 \times$ $4.57 \mathrm{~m}$ ) within a naturally ventilated barn at the Iowa State University Dairy Farm (Ames) and were allowed $4 \mathrm{~d}$ to acclimate. The trial consisted of 2 experimental periods $(\mathbf{P})$. During P1 (4 d), cows were housed in thermoneutral conditions $\left(21.0 \pm 0.3^{\circ} \mathrm{C}, 63.0 \pm 0.6 \%\right.$ relative humidity; temperature-humidity index of 67 ) with ad libitum feed intake. During P2 (4 d), cows were randomly assigned within parity to 1 of 2 groups: (1) thermoneutral conditions and pair-fed $(\mathbf{P F} ; \mathrm{n}=8)$ or
(2) HS induced artificially by an EHB with ad libitum feed intake (EHB; $n=10)$. Cows were fitted with an EHB consisting of 12 infrared heating pads as a heat source (Thermotex Therapy Systems Ltd., Calgary, $\mathrm{AB}$, Canada); the EHB remained on the cows for the entirety of P2. The blanket was powered by a $110-\mathrm{V}$ electrical cord that connected to the EHB at the withers as previously described (Al-Qaisi et al., 2019). One cow from the EHB group was excluded from the trial due to illness unrelated to the blanket, and her data were not incorporated in the final data set. During P2, the PF cows were pair-fed to their EHB counterparts to eliminate the confounding effects of dissimilar nutrient intake as we have described previously (Rhoads et al., 2009; Wheelock et al., 2010; Baumgard et al., 2011). In brief, the P1 feed intake was averaged for each cow and used as a baseline. For each EHB cow, the decrease in feed intake during P2 was calculated as a percentage of feed intake reduction relative to $\mathrm{P} 1$ for each day of heat exposure. The percentage of feed intake reduction was averaged for all cows in the EHB group per day of heat exposure and applied individually to the baseline of each cow in the PF group. The daily amount of feed provided to the PF group was divided equally into 2 portions during P2 ( 0800 and $1800 \mathrm{~h})$ to minimize large metabolic changes associated with gorging.

Ambient temperature and relative humidity were monitored and recorded every $10 \mathrm{~min}$ by a data logger (EL-USB-2 LCR, Lascar Electronics, Erie, PA) and condensed into a daily average. Cows were housed in thermoneutral ambient conditions throughout P2 (23.2 $\pm 0.1^{\circ} \mathrm{C}, 59.4 \pm 0.4 \%$ relative humidity, temperaturehumidity index of 70).

Cows were individually fed a TMR consisting primarily of corn silage once daily (0800 h), and orts were measured before feeding. The TMR was formulated to meet or exceed the predicted requirements (NRC, 2001) of energy, protein, minerals, and vitamins for lactating cows (Table 1). Cows were milked twice daily (0600 and $1800 \mathrm{~h}$ ), and yield was recorded. Milk samples from each cow were collected daily during both experimental periods. Samples were stored at $4^{\circ} \mathrm{C}$ with a preservative (bronopol tablet; D\&F Control Systems, San Ramon, CA) until analysis by Dairy Lab Services (Dubuque, IA) using AOAC-approved infrared analysis equipment and procedures (AOAC International, 1995).

During both $\mathrm{P} 1$ and $\mathrm{P} 2$, rectal temperature $(\mathbf{T r})$, skin temperature $(\mathbf{T s})$, respiration rate $(\mathbf{R R})$, and heart rate (HR) were obtained twice daily (0600 and $1800 \mathrm{~h}$ ). Rectal temperatures were measured using a standard digital thermometer (M700 digital thermometer, GLA Agricultural Electronics, San Luis Obispo, CA). Skin temperatures were measured on the neck using an infrared thermometer (IRT207 Heat Seeker 
8:1 mid-range infrared thermometer, General Tools and Instruments, New York, NY). Respiration rates were determined by counting flank movements during a 15-s interval and multiplied by 4 to obtain breaths per minute. Heart rate was determined using a stethoscope placed over the left side of the rib cage behind the elbow, and heart beats were counted for a 15-s interval. This measurement was multiplied by 4 to obtain beats per minute.

Continuous vaginal temperatures $(\mathbf{T v})$ were obtained via a calibrated temperature logger (iButton DS 1921, Maxim Integrated, San Jose, CA) fitted in a hollowedout space in the center of a blank controlled internal drug release device (CIDR; Zoetis, Parsippany, NJ) and inserted into the vagina with an applicator. Loggers were fixed in the CIDR using a silicone aquarium sealant (Aqueon, Franklin, WI). Vaginal temperatures were obtained every $10 \mathrm{~min}$ for 6 consecutive days (from d 3 of P1 to d 4 of P2). Time of CIDR insertion and removal were recorded. Data collected within the first hour of CIDR insertion were removed to guarantee the precision of the temperature measurements.

Blood samples were collected via coccygeal venipuncture (plasma, $\mathrm{K}_{2}$ EDTA tube; BD Vacutainers, Franklin Lakes, NJ) on d 2 and 4 of both P1 and P2 following the morning milking. Plasma was harvested following centrifugation at $1,500 \times g$ for $15 \mathrm{~min}$ at $4^{\circ} \mathrm{C}$ and was subsequently frozen at $-20^{\circ} \mathrm{C}$ until analysis.

Plasma insulin, nonesterified fatty acids (NEFA), and BUN concentrations were determined using commercially available kits according to manufacturers' instructions (insulin, Mercodia AB, Uppsala, Sweden;

Table 1. Ingredients and composition of $\operatorname{diet}^{1}$

\begin{tabular}{lc}
\hline Item & \% of DM \\
\hline Ingredient & \\
Corn silage & 30.0 \\
Alfalfa hay & 12.1 \\
Ground corn & 28.6 \\
Mineral and protein mix & 4.3 \\
Corn gluten feed & 6.7 \\
Soybean meal & 5.4 \\
SoyPlus ${ }^{2}$ & 7.1 \\
Molasses & 1.8 \\
Straw & 3.2 \\
Bypass fat & \\
Chemical analysis & 0.8 \\
Starch & \\
CP & 26.6 \\
NDF & 16.6 \\
ADF & 32.3 \\
NE & 21.4 \\
I Mcal/kg of DM) & 1.61
\end{tabular}

${ }^{1}$ Values represent an average of ration nutrient summary reports collected throughout the trial. Diet DM averaged $50.45 \%$.

${ }^{2}$ SoyPlus mechanically processed soybean meal, Dairy Nutrition Plus, Ralston, IA.

${ }^{3}$ MagnaPalm, Energy Feeds International, Lago Vista, TX.
NEFA, Wako Chemicals USA, Richmond, VA; BUN, Teco Diagnostics Anaheim, CA). The inter- and intraassay coefficients of variation for insulin, NEFA, and BUN assays were 11.5 and $4.2 \%, 4.5$ and $5.3 \%$, and 10.0 and $5.9 \%$, respectively.

Blood gas analysis and circulating ionized calcium and glucose were measured on fresh blood collected on d 4 of P1 and d 2 and 4 of P2 into lithium heparin tubes and assayed immediately using an i-STAT handheld blood analyzer (CG8+ cartridge, MN:300-G; Abbott Point of Care Inc., Abbott Park, IL).

\section{Statistical Analysis}

Data were statistically analyzed using SAS software (version 9.4; SAS Institute Inc., Cary, NC). Body temperature indices, production parameters, and blood metabolites were analyzed using the MIXED procedure of SAS with an autoregressive covariance structure and day of the experiment as the repeated effect. The model included group, day, and group by day interaction. Each specific variable's P1 value served as a covariate. In addition, the effects of period were analyzed separately using the MIXED procedure of SAS. The model included group, period, and their interaction; cow was included as a random effect. Results are reported as least squares means and were considered different when $P \leq 0.05$ and a tendency if $0.05<P \leq 0.10$.

\section{RESULTS}

During P1, all body temperature indices were similar for cows destined to be in the PF and EHB groups. As expected, during P2, the EHB markedly increased Tr and $\operatorname{Tv}\left(1.4\right.$ and $1.3^{\circ} \mathrm{C}$, respectively; $P<0.01$; Figure 1) relative to that of PF cows. Similarly, Ts increased $\left(0.8^{\circ} \mathrm{C} ; P<0.01\right.$; Table 2$)$ in the EHB cows compared with the PF controls. Furthermore, HS conditions induced by the EHB increased RR and HR (42 breaths/ min and 17 beats/min, respectively; $P<0.01$; Table 2 ) relative to those of the $\mathrm{PF}$ group.

Overall during P2, EHB reduced DMI (47\%; $P<$ 0.01 ) relative to $\mathrm{P} 1$; by experimental design, the $\mathrm{PF}$ cows had a similar pattern and extent of decreased DMI (Table 3; Figure 2A). Milk yield decreased ( $P=$ $0.03)$ in EHB and PF cows by $27.3 \%(12.1 \mathrm{~kg})$ and $13.4 \%$ (5.4 kg), respectively, compared with P1 (Table 3 ; Figure 2B). Milk fat content tended to increase $(19 \%$; $P=0.08$; Table 3$)$ in the EHB cows, and it remained similar in the PF controls relative to P1. During P2, milk protein content tended to decrease $(1.3 \% ; P=$ 0.09; Table 3 ) in both EHB and PF groups. In addition, both EHB and PF cows had decreased $(P<0.01)$ milk lactose content (4.96\% in P1 vs. $4.85 \%$ in P2; Table 3 ). 
A)
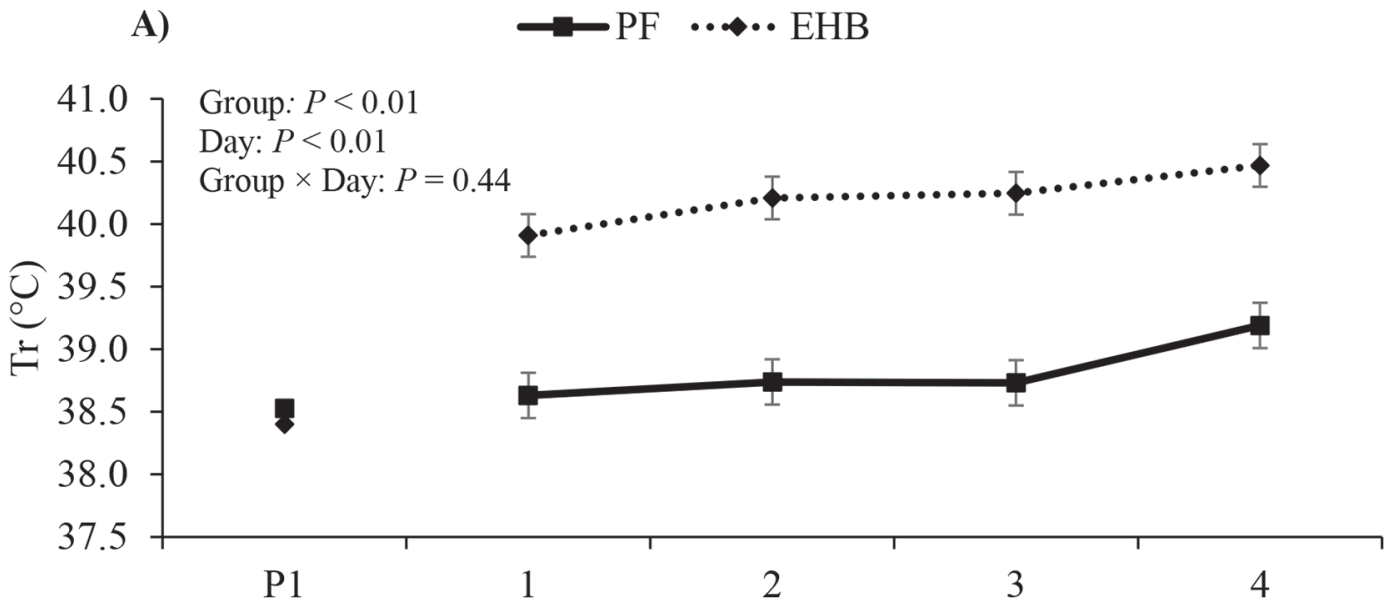

B)

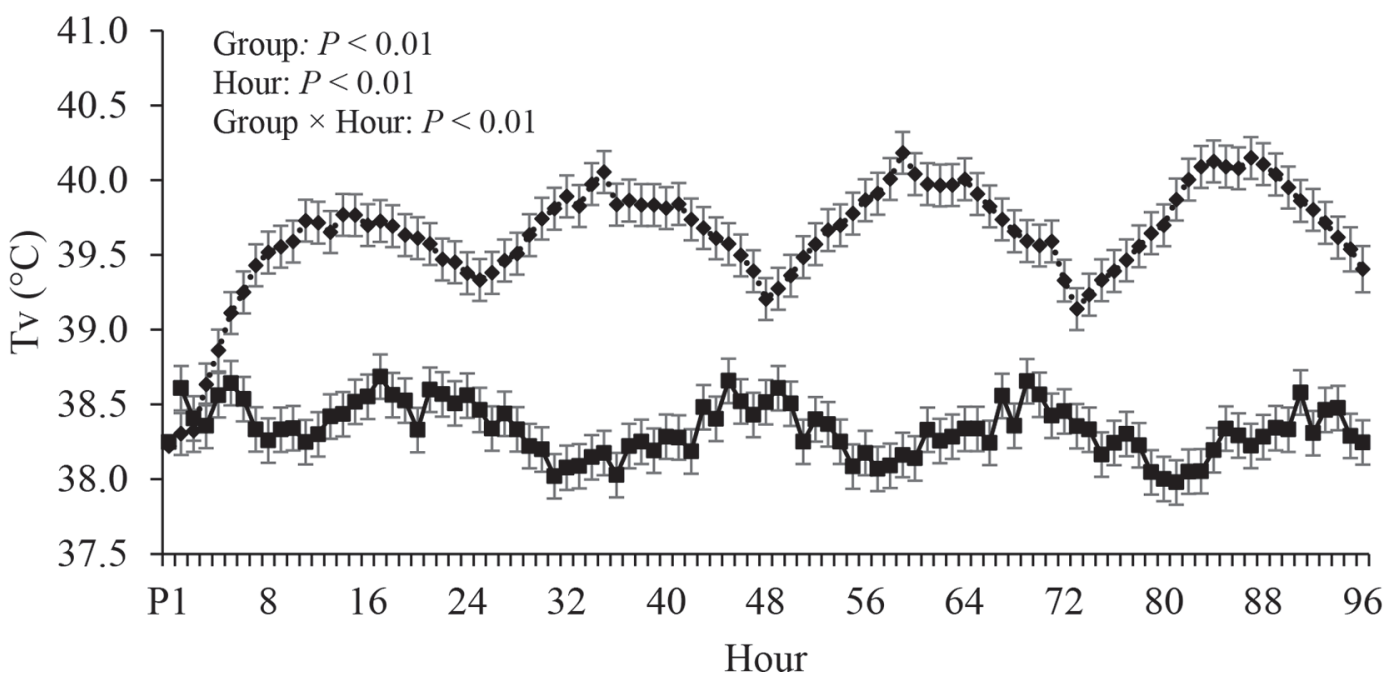

Figure 1. Effects of pair-feeding $(\mathrm{PF})$ or electric heat blanket (EHB) on (A) rectal temperature $(\mathrm{Tr})$, and (B) hourly vaginal temperature $(\mathrm{Tv})$ in lactating Holstein cows. Values for P1 represent the average of the $4 \mathrm{~d}$ of period 1 and are used as a covariate for period 2. Results are expressed as LSM \pm SEM.

During P2, milk SCC increased $(31 \% ; P=0.04$; Table 3 ) in both groups relative to P1. There was a group by period interaction on MUN; it remained unchanged in PF controls, but increased in EHB cows $(34.2 \%$; $P<$ 0.01; Table 3) relative to $\mathrm{P} 1$.
During P2, circulating glucose decreased progressively with time $(P=0.02)$ similarly between groups $(P=0.87$; Figure 3A). Compared with $\mathrm{P} 1$, circulating insulin decreased $(44 \% ; P<0.01$; Figure $3 \mathrm{~B})$ and this decrease was similar between groups during P2 $(P=$

Table 2. Effects of pair-feeding (PF) or electric heat blanket (EHB) on physiological indicators in lactating Holstein cows

\begin{tabular}{|c|c|c|c|c|c|c|c|c|}
\hline Variable & \multicolumn{2}{|c|}{ Period $1^{1}$} & \multicolumn{2}{|c|}{ Period $2^{2}$} & SEM & \multicolumn{3}{|c|}{$P$-value } \\
\hline Skin temperature $\left({ }^{\circ} \mathrm{C}\right)$ & $31.8^{\mathrm{c}}$ & $31.8^{\mathrm{c}}$ & $32.6^{\mathrm{b}}$ & $33.4^{\mathrm{a}}$ & 0.3 & 0.32 & $<0.01$ & 0.03 \\
\hline Heart rate (beats/min) & $80^{\mathrm{b}}$ & $79^{\mathrm{b}}$ & $75^{\mathrm{c}}$ & $92^{\mathrm{a}}$ & 1 & $<0.01$ & $<0.01$ & $<0.01$ \\
\hline
\end{tabular}

${ }^{\mathrm{a}-\mathrm{c}}$ Values within a row with differing superscripts differ significantly $(P<0.05)$.

${ }^{1}$ During period 1, cows in both PF and EHB were treated similarly (housed in thermoneutral conditions and fed ad libitum).

${ }^{2}$ During period 2, cows were pair-fed and kept in thermoneutral conditions or fitted with EHB and fed ad libitum. 
0.31; Figure 3B). A group by day interaction was observed for circulating NEFA; it progressively increased in the PF controls but remained unchanged in the $\mathrm{EHB}$ cows during P2 $(P=0.03$; Figure $3 \mathrm{C})$. In addition, a group by period interaction was detected for plasma BUN levels, which remained stable in the PF controls but increased in the EHB cows $(37 \% ; P<0.01$; Table $3)$.

During P2, decreased partial pressure of $\mathrm{CO}_{2}, \mathrm{HCO}_{3}$, total $\mathrm{CO}_{2}$, and base excess levels $(17,16,17$, and $81 \%$, respectively; $P<0.01$; Figure $4 \mathrm{~A}-\mathrm{D}$ ) were observed in the EHB cows compared with PF controls. Hematocrit and hemoglobin increased in both EHB and PF groups (3.1\%; $P \leq 0.05$; Table 4) relative to $\mathrm{P} 1$. Circulating sodium remained unchanged in the EHB cows but decreased in the PF controls $(1.5 \% ; P<0.01$; Table 4) relative to $\mathrm{P} 1$. No group differences were observed for ionized calcium or the remaining iSTAT blood parameters during P2 $(P>0.10$; Table 4$)$.

\section{DISCUSSION}

Suboptimal environmental conditions are detrimental to farm animal productivity. When the ambient temperature is below or above the thermoneutral zone, efficiency and profitability are compromised because nutrients are diverted away from productive purposes to maintain euthermia (Baumgard and Rhoads, 2012). Accurately studying HS typically requires expensive climate-controlled facilities (especially if experimental objectives are to distinguish between the direct and indirect effects of HS), infrastructure inaccessible to most scientists. Thus, we have developed a model uti- lizing an EHB and demonstrated that it is an effective and pragmatic technique to study HS in dairy cows (Al-Qaisi et al., 2019). Utilizing the EHB broadens the accessibility of the thermal biology discipline because it is relatively easy and cheap, and it is conducive to flexible experimental designs. However, quantifying the contribution of direct and indirect (i.e., reduced feed intake) effects of HS has not been determined in the EHB model. Thus, it is of interest to determine the contribution of the nutritional plane to altered metabolism and productivity in the EHB model.

In the current study, the EHB caused marked hyperthermia, as demonstrated by an increase in all body temperature variables relative to both $\mathrm{P} 1$ and the PF controls, confirming that the EHB is capable of implementing a substantial heat load. The magnitude of changes in the thermal indices agrees with our previous EHB study (Al-Qaisi et al., 2019) and climate-controlled experiments (Rhoads et al., 2009; Wheelock et al., 2010; Baumgard et al., 2011; Cowley et al., 2015). However, from the perspective of thermal indices, "acclimation" was not observed: $\mathrm{Tr}, \mathrm{Tv}$, and $\mathrm{RR}$ remained equally increased at the end of P2 as they did on $\mathrm{d}$ 1 of P2. Although consistent with our previous EHB experiment (Al-Qaisi et al., 2019), a lack of acclimation differs from what is normally observed in natural HS (Kadzere et al., 2002) and climate-controlled HS experiments (Rhoads et al., 2009; Wheelock et al., 2010). Reasons for the discrepancies are not entirely clear, but the length of P2 was shorter than in previous climatecontrolled experiments ( $4 \mathrm{~d}$ vs. 7-10 d) and there may have been insufficient time to express the acclimation phenotype. Further, it is very likely that upregulated

Table 3. Effects of pair-feeding (PF) or electric heat blanket (EHB) on production and metabolism variables in lactating Holstein cows

\begin{tabular}{|c|c|c|c|c|c|c|c|c|}
\hline \multirow[b]{2}{*}{ Variable } & \multicolumn{2}{|c|}{ Period $1^{1}$} & \multicolumn{2}{|c|}{ Period $2^{2}$} & \multirow[b]{2}{*}{ SEM } & \multicolumn{3}{|c|}{$P$-value } \\
\hline & $\mathrm{PF}$ & $\mathrm{EHB}$ & $\mathrm{PF}$ & $\mathrm{EHB}$ & & Group & Period & Group $\times$ period \\
\hline DMI $(\mathrm{kg} / \mathrm{d})$ & 25.5 & 27.7 & 14.0 & 14.8 & 1.0 & 0.27 & $<0.01$ & 0.23 \\
\hline Milk yield (kg/d) & $40.2^{\mathrm{a}}$ & $44.3^{\mathrm{a}}$ & $34.8^{\mathrm{b}}$ & $32.2^{\mathrm{b}}$ & 2.6 & 0.84 & $<0.01$ & $<0.01$ \\
\hline $3.5 \%$ FCM $(\mathrm{kg} / \mathrm{d})$ & $40.2^{\mathrm{a}}$ & $43.3^{\mathrm{a}}$ & $36.2^{\mathrm{b}}$ & $33.6^{\mathrm{b}}$ & 2.1 & 0.93 & $<0.01$ & $<0.01$ \\
\hline $\operatorname{ECM}(\mathrm{kg} / \mathrm{d})$ & $40.7^{\mathrm{a}}$ & $43.1^{\mathrm{a}}$ & $36.2^{\mathrm{b}}$ & $33.0^{\mathrm{b}}$ & 2.1 & 0.89 & $<0.01$ & $<0.01$ \\
\hline \multicolumn{9}{|l|}{ Milk variables } \\
\hline Fat $(\%)$ & 3.53 & 3.45 & 3.76 & 4.09 & 0.23 & 0.68 & $<0.01$ & 0.08 \\
\hline Fat $(\mathrm{kg} / \mathrm{d})$ & $1.41^{\mathrm{ab}}$ & $1.49^{\mathrm{a}}$ & $1.30^{\mathrm{ab}}$ & $1.21^{\mathrm{b}}$ & 0.07 & 0.97 & $<0.01$ & 0.03 \\
\hline Protein (\%) & 3.22 & 2.95 & 3.15 & 2.94 & 0.07 & 0.04 & 0.09 & 0.13 \\
\hline Protein $(\mathrm{kg} / \mathrm{d})$ & $1.29^{\mathrm{a}}$ & $1.30^{\mathrm{a}}$ & $1.10^{\mathrm{b}}$ & $0.94^{\mathrm{b}}$ & 0.07 & 0.39 & $<0.01$ & $<0.01$ \\
\hline Lactose $(\%)$ & 4.97 & 4.94 & 4.87 & 4.83 & 0.06 & 0.66 & $<0.01$ & 0.80 \\
\hline Lactose (kg/d) & $2.00^{\mathrm{a}}$ & $2.19^{\mathrm{a}}$ & $1.71^{\mathrm{b}}$ & $1.59^{\mathrm{b}}$ & 0.14 & 0.85 & $<0.01$ & $<0.01$ \\
\hline SCC $(\times 1,000$ cells $)$ & 40 & 25 & 46 & 39 & 10 & 0.43 & 0.04 & 0.34 \\
\hline $\operatorname{MUN}(\mathrm{mg} / \mathrm{dL})$ & $13.8^{\mathrm{b}}$ & $12.0^{\mathrm{c}}$ & $13.9^{\mathrm{b}}$ & $16.1^{\mathrm{a}}$ & 0.6 & 0.82 & $<0.01$ & $<0.01$ \\
\hline ECM/DMI (kg/kg) & 1.59 & 1.56 & 2.60 & 2.44 & 0.11 & 0.46 & $<0.01$ & 0.42 \\
\hline $\operatorname{BUN}(\mathrm{mg} / \mathrm{dL})$ & $10.8^{\mathrm{c}}$ & $12.9^{\mathrm{b}}$ & $11.0^{\mathrm{c}}$ & $17.7^{\mathrm{a}}$ & 0.7 & $<0.01$ & $<0.01$ & $<0.01$ \\
\hline
\end{tabular}

\footnotetext{
${ }^{a-c}$ Values within row of each variable with differing superscripts indicate significant difference $(P<0.05)$.

${ }^{1}$ During period 1, cows in both PF and EHB were treated similarly (housed in thermoneutral conditions and fed ad libitum).

${ }^{2}$ During period 2, cows were pair-fed and kept in thermoneutral conditions or fitted with EHB and fed ad libitum.
} 
heat-dissipation mechanisms (e.g., sweating) are key components of "acclimation" and the blanket would obviously interfere with this strategy.

As expected, the EHB decreased DMI (47\%) similarly to our previous EHB trial (Al-Qaisi et al., 2019); by experimental design, the PF group had a comparable pattern of decreased DMI during P2. Reduced DMI is a common response during HS and it likely represents a survival strategy to decrease metabolic heat production (Collin et al., 2001; Kadzere et al., 2002; Baumgard and Rhoads, 2013). Milk yield was decreased in the EHB and PF group by 27.3 and $13.4 \%$, respectively, relative to P1, indicating that reduced DMI accounted for only $\sim 50 \%$ of decreased milk yield. This is consistent with HS studies conducted in environmental chambers (Rhoads et al., 2009; Wheelock et al., 2010; Baumgard et al., 2011; Cowley et al., 2015; Gao et al., 2017). Thus, by using the PF design, we were able to confirm that a similar nutrient intake:milk production relationship exists with the EHB model.

During P2, the EHB cows had increased milk fat content (19\%; Table 3), which corroborates most HS studies conducted in environmental chambers (Regan and Richardson, 1938; Rhoads et al., 2009). Contrarily, milk fat content typically decreases during the warm summer months (Hays, 1926; Huber, 1996; Bouraoui et al., 2002). Additionally, some data generated from environmental chambers demonstrated that milk fat content did not change in HS cows (Shwartz et al., 2009; Cowley et al., 2015). Regardless, the increase in milk fat content is certainly not due to excessive adipose mobilization as circulating NEFA were decreased

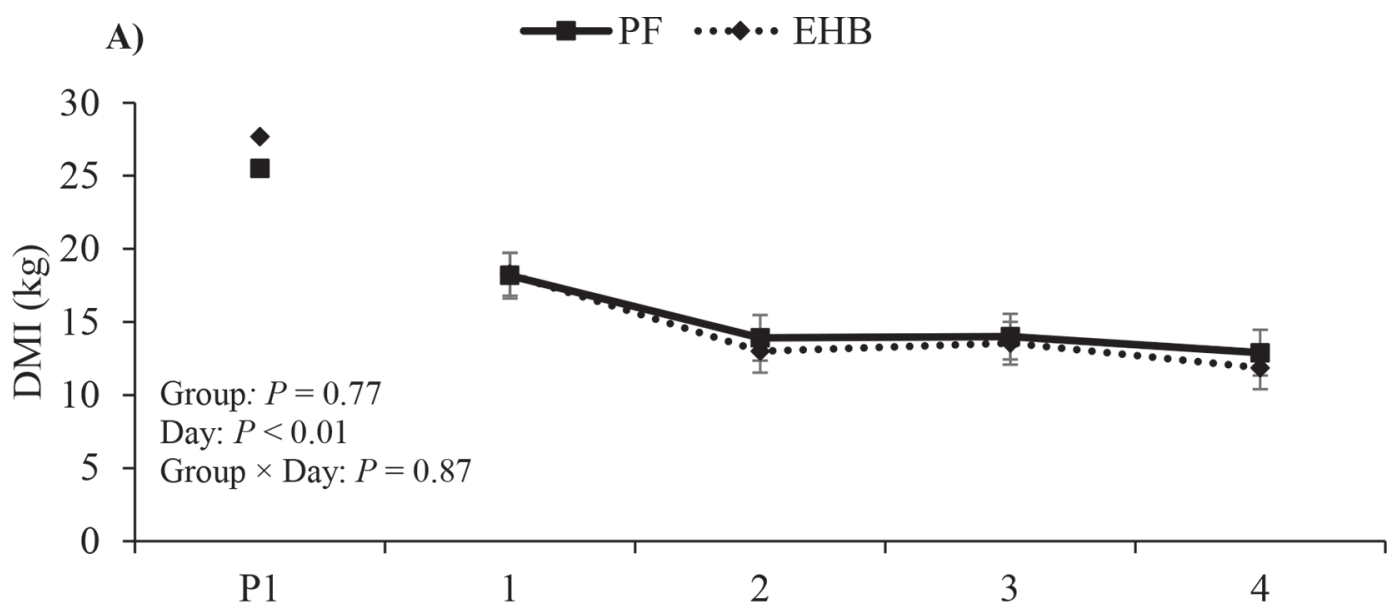

B)

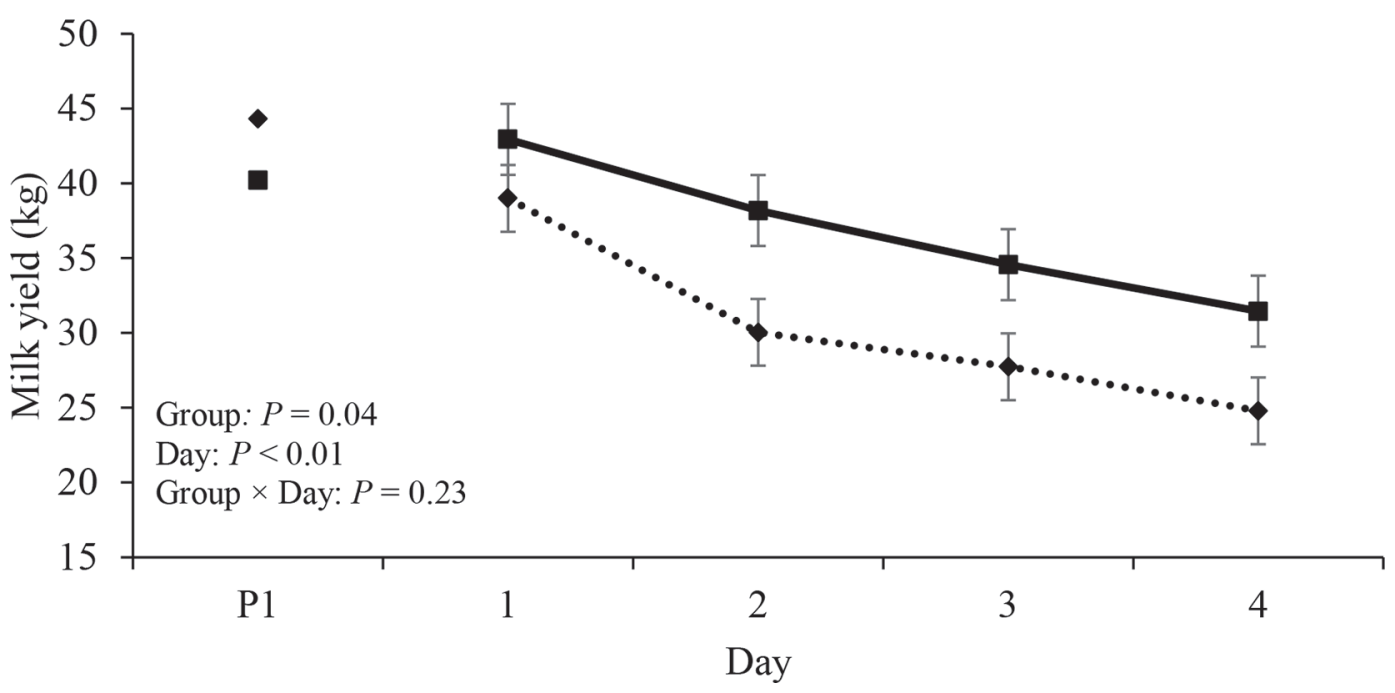

Figure 2. Effects of pair-feeding (PF) or electric heat blanket (EHB) on (A) DMI, and (B) milk yield in lactating Holstein cows. Values for $\mathrm{P} 1$ represent the average of the $4 \mathrm{~d}$ of period 1 and are used as a covariate for period 2. Results are expressed as LSM \pm SEM. 
during HS. Consequently, it is clear that factors other than HS (e.g., sunlight, eating patterns, forage digestibility) contribute to low summer milk fat content. Milk lactose concentrations slightly decreased in both EHB and PF groups (2.2\%; Table 3$)$ during P2, which agrees with previous reports (Nardone et al., 1997; Rhoads et al., 2009; Shwartz et al., 2009; Wheelock et al., 2010). Factors explaining the decreased milk lactose content are not clear, but extra-mammary glucose utilization appears to increase during HS (Wheelock et al., 2010) and this restructuring in the hierarchy of glucose trafficking may help explain the decrease in lactose content. During P2, milk protein content decreased in both groups, which agrees with our recent EHB study (Al-Qaisi et al., 2019) and previous climate-controlled experiments (Rhoads et al., 2009; Shwartz et al., 2009;
Wheelock et al., 2010; Cowley et al., 2015), which likely indicates that protein synthesis in the mammary gland is downregulated (Cowley et al., 2015) or AA are partitioned away from mammary gland (Gao et al., 2017). Additionally, the EHB increased MUN, which agrees with our recent results (Al-Qaisi et al., 2019) and previous reports from HS studies in environmental chambers (Wheelock et al., 2010; Cowley et al., 2015; Gao et al., 2017). The explanation for why milk MUN increases is discussed below.

As mentioned above, direct effects of HS (independent of feed intake) are characterized by postabsorptive changes in carbohydrate, lipid, and protein metabolism. In the present study, circulating glucose was decreased for both the EHB and PF cows during P2. This response corroborates previous HS results in dairy cows (Itoh et

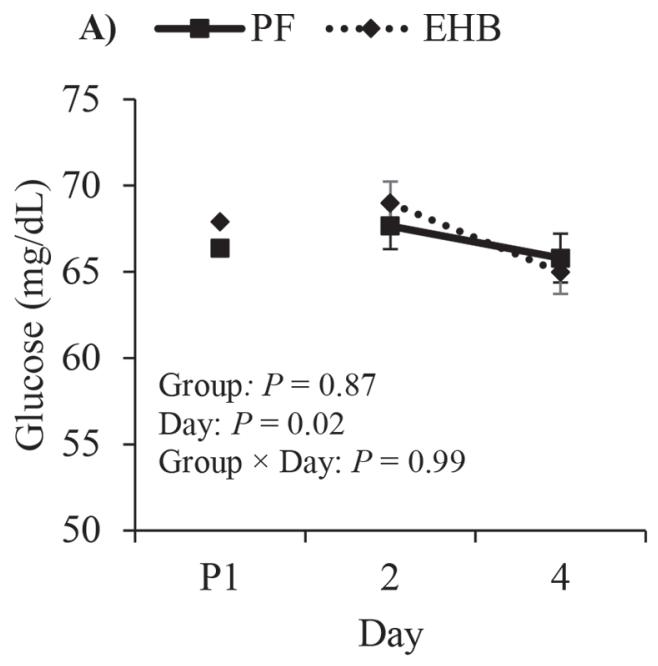

\section{B) $\quad \square \mathrm{PF}$ 圆 $\mathrm{EHB}$}

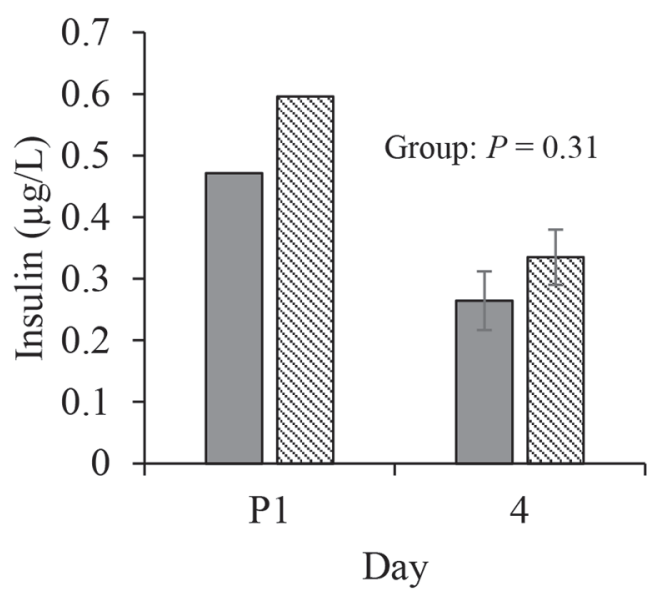

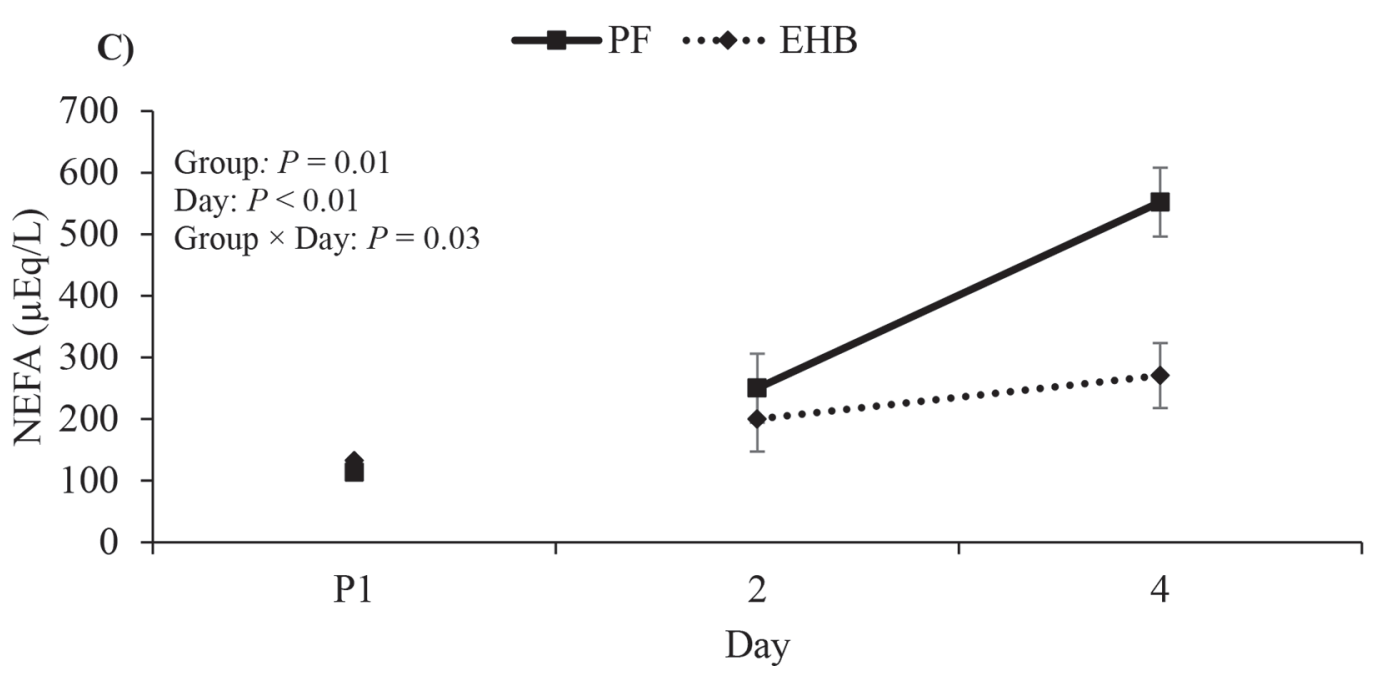

Figure 3. Effects of pair-feeding ( $\mathrm{PF}$ ) or electric heat blanket (EHB) on circulating $(\mathrm{A})$ glucose, $(\mathrm{B})$ insulin, and $(\mathrm{C})$ nonesterified fatty acid (NEFA) in lactating Holstein cows. Values for P1 represent the average of d 2 and $4 \mathrm{~d}$ of period 1 and are used as a covariate for period 2. Results are expressed as LSM \pm SEM. 


\section{$\rightarrow \mathrm{PF} \quad \cdots \bullet \cdot \mathrm{EHB}$}

A)

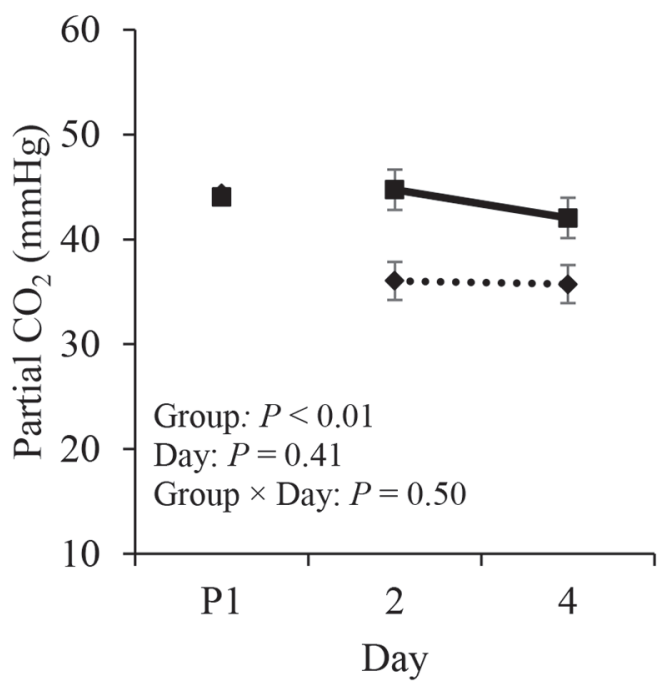

C)

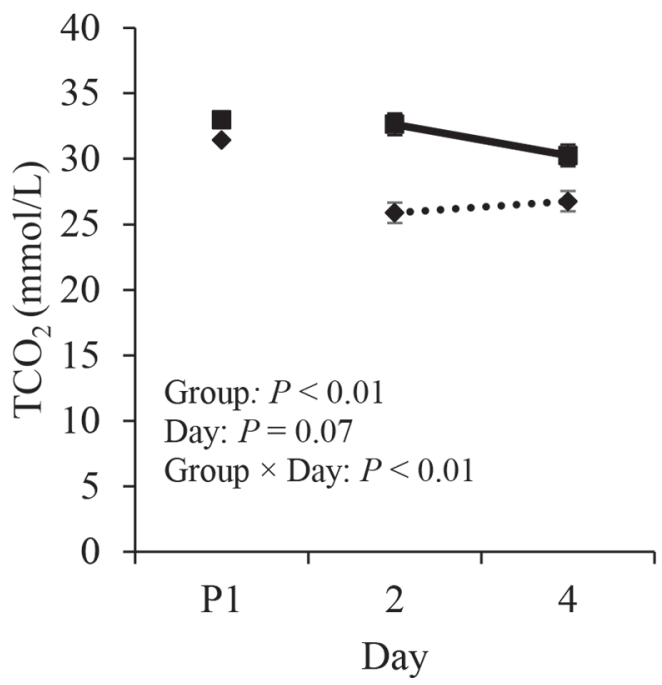

B)

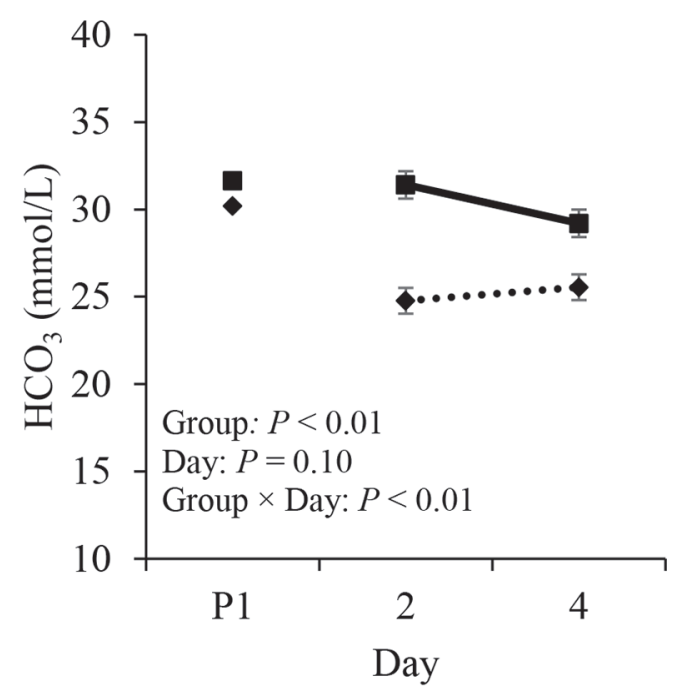

D)

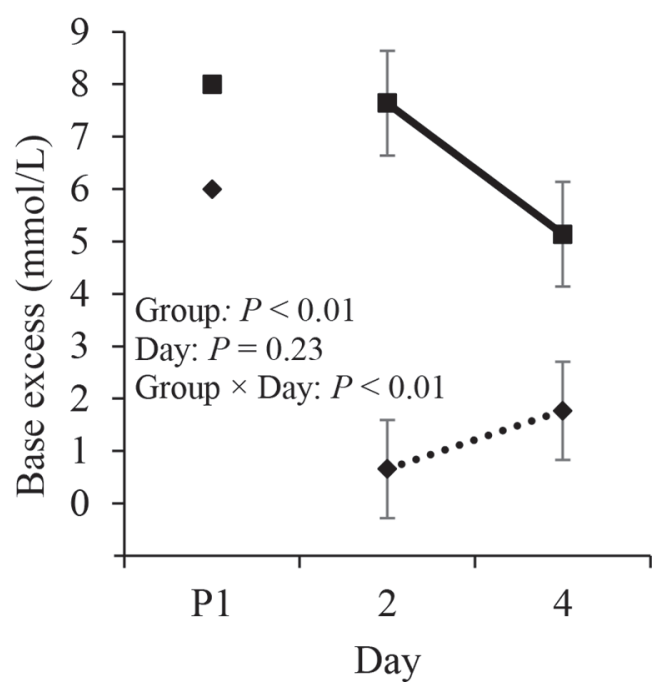

Figure 4. Effects of pair-feeding (PF) or electric heat blanket (EHB) on blood (A) partial pressure of carbon dioxide, (B) bicarbonate $\left(\mathrm{HCO}_{3}\right),(\mathrm{C})$ total carbon dioxide $\left(\mathrm{TCO}_{2}\right)$, and (D) base excess levels in lactating Holstein cows. Values for P1 represent the average of d 4 of period 1 and are used as a covariate for period 2. Results are expressed as LSM \pm SEM.

al., 1998; Rhoads et al., 2009; Wheelock et al., 2010), sheep (Achmadi et al., 1993), and pigs (Sanz Fernandez et al., 2014). The exact reasons why HS decreases blood glucose are not fully clear, but reduced DMI (and thus reduced propionate delivery) and increased glucose uptake by the immune system (Kvidera et al., 2017) are 2 possible explanations. Immune activation occurs because HS reduces intestinal barrier integrity, a scenario that allows LPS (and presumably thousands of potential antigens) to infiltrate into local and systemic circulation (Lambert, 2009; Baumgard and Rhoads, 2013; Sanz Fernandez et al., 2014; Koch et al., 2019).

Insulin plays a key role in nutrient partitioning because it is the major acute anabolic hormone controlling carbohydrate, lipid, and protein metabolism (as reviewed by Baumgard et al., 2016). Our previous results showed that insulin concentrations increased in lactating dairy cows (Wheelock et al., 2010), growing calves (O'Brien et al., 2010), pigs (Pearce et al., 2013; Mayorga et al., 2018), and snakes (Gangloff et 
Table 4. Effects of pair-feeding (PF) or electric heat blanket (EHB) on blood variables in lactating Holstein cows

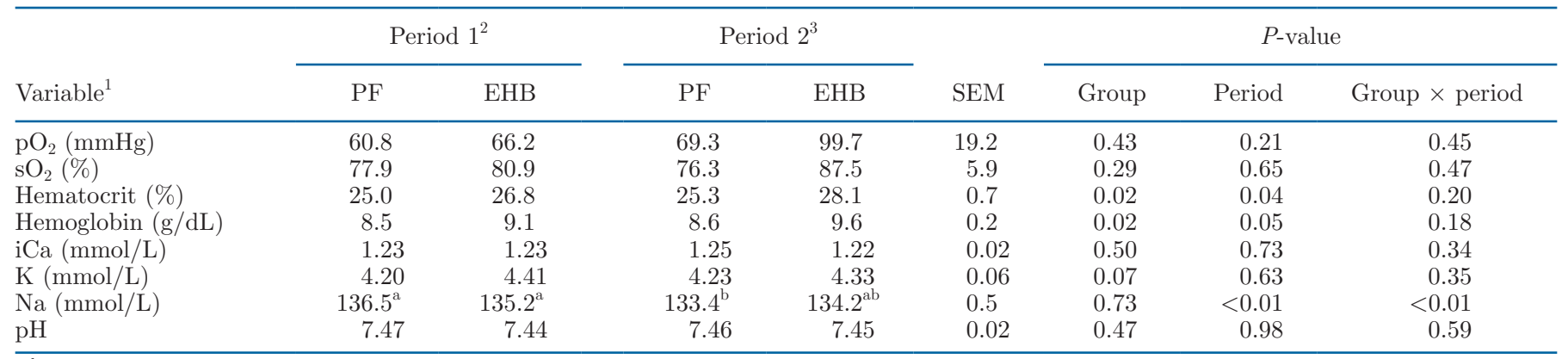

${ }^{\mathrm{a}-\mathrm{b}}$ Values within row of each variable with differing superscripts indicate significant difference $(P<0.05)$.

${ }^{1} \mathrm{pO}_{2}=$ partial pressure of $\mathrm{O}_{2} ; \mathrm{sO}_{2}=$ oxygen saturation; $\mathrm{iCa}=$ ionized calcium.

${ }^{2}$ During period 1, cows in both PF and EHB were treated similarly (housed in thermoneutral conditions and fed ad libitum).

${ }^{3}$ During period 2, cows were pair-fed and kept in thermoneutral conditions or fitted with EHB and fed ad libitum.

al., 2016) during HS. Circulating insulin was decreased for both the EHB and PF cows during P2 compared with P1. Reasons for not observing a statistical effect in circulating insulin in this experiment are not clear, but insulin concentrations were determined just once during P2 (i.e., d 4), which may have been too infrequent to make meaningful biological interpretations or a strong statistical analysis.

Suboptimal feed intake in lactating cows induces homeorhetic changes to support the physiological state of lactation. This is primarily characterized by enhanced adipose tissue lipolysis and increased use of NEFA as an energy source, a key mechanistic strategy that spares glucose for milk synthesis (Bauman and Currie, 1980; Baumgard et al., 2017). In the current study, the PF cows had markedly increased circulating NEFA, as expected because they were on a lower plane of nutrition. However, circulating NEFA in the EHB cows remained at basal levels despite the reduction in DMI, which supports ours and previous ruminant (Sano et al., 1983; Itoh et al., 1998; Rhoads et al., 2009; Shwartz et al., 2009; Wheelock et al., 2010; Al-Dawood, 2017) and monogastric (Geraert et al., 1996; Pearce et al., 2013; Sanz Fernandez et al., 2015) results.

As stated earlier, protein metabolism is also affected during a heat load. Skeletal muscle proteolysis is ostensibly increased during HS, as indicated by elevated plasma markers of muscle catabolism such as creatine, 3-methylhistidine, and BUN (Baumgard and Rhoads, 2013; Gao et al., 2017; Conte et al., 2018). In agreement with HS studies conducted in environmental chambers (Rhoads et al., 2009; Wheelock et al., 2010; Cowley et al., 2015; Gao et al., 2017), the EHB caused increased BUN levels (37\%) during P2, likely a product of excessive AA deamination stemming from the need to provide AA for gluconeogenesis and acute phase protein synthesis (Baumgard and Rhoads, 2013).
Evaporation is the primary route of heat dissipation when ambient temperatures are near an animal's body temperature, and this is predominantly achieved by 2 routes: sweating and panting (hyperventilation; Kadzere et al., 2002). During HS, the amount of $\mathrm{CO}_{2}$ exhaled through rapid respiration is increased, and thus panting eventually decreases blood $\mathrm{CO}_{2}$, leading to transient respiratory alkalosis (Kadzere et al., 2002; Conte et al., 2018). To keep a constant ratio of $\mathrm{HCO}_{3}$ : $\mathrm{CO}_{2}(20: 1)$ to maintain the primary circulatory buffering system, $\mathrm{HCO}_{3}$ secretion in the urine increases in $\mathrm{HS}$ cows (Kadzere et al., 2002; Conte et al., 2018). Consequently, the salivary $\mathrm{HCO}_{3}$ pool, which is essential to maintain a healthy rumen $\mathrm{pH}$, is decreased, making the HS dairy cow more prone to rumen acidosis (Kadzere et al., 2002). In the current study, the EHB decreased partial pressure of $\mathrm{CO}_{2}, \mathrm{HCO}_{3}$, total $\mathrm{CO}_{2}$, and base excess levels relative to $\mathrm{PF}$ controls, which agrees with others (Schneider et al., 1984; West et al., 1991). Additionally, hematocrit increased in both groups, which likely indicates that EHB cows become mildly dehydrated, which agrees with previous reports (Michel et al., 2007; Das et al., 2016). Consequently, the aforementioned physiological variables also indicate that the EHB induces HS in a similar way to climate-controlled chambers and natural HS.

\section{CONCLUSIONS}

Understanding the biological reasons why HS reduces production is a prerequisite to developing mitigation strategies aimed at reducing economic losses to the global dairy industry. This study confirms that the EHB is an effective model to study HS in dairy cows, as indicated by increased body temperature variables, reduced production parameters, and altered physiological metrics. By employing the PF design, we clearly il- 
lustrated that a lowered nutritional plane explains only approximately $50 \%$ of the decreased milk yield in HS cows, which is remarkably similar to results from previous environmental chamber studies. In addition, the blunted adipose tissue mobilization, increased plasma biomarkers of muscle catabolism, and altered blood gas variables observed for the EHB are comparable to results in natural and climate-controlled chamber HS studies. Consequently, the EHB is an alternative model to implement discovery-based research and to evaluate nutritional HS mitigation strategies.

\section{ACKNOWLEDGMENTS}

The study described herein was funded in part by the Norman Jacobson Endowed Professorship at Iowa State University, Ames. The authors state that they have no conflicts of interest.

\section{REFERENCES}

Achmadi, J., T. Yanagisawa, H. Sano, and Y. Terashima. 1993. Pancreatic insulin secretory response and insulin action in heat exposed sheep given a concentrate or roughage diet. Domest. Anim. Endocrinol. 10:279-287. https://doi.org/10.1016/0739-7240(93)90032-7.

Al-Dawood, A. 2017. Effect of heat stress on adipokines and some blood metabolites in goats from Jordan. Anim. Sci. J. 88:356-363. https://doi.org/10.1111/asj.12636.

Al-Qaisi, M., E. A. Horst, S. K. Kvidera, E. J. Mayorga, L. L. Timms, and L. H. Baumgard. 2019. Technical note: Developing a heat stress model in dairy cows using an electric heat blanket. J. Dairy Sci. 102:684-689. https://doi.org/10.3168/jds.2018-15128.

AOAC International. 1995. Official method 972.16. Fat, lactose, protein, and solids in milk. Mid infrared spectroscopic method. Pages 23-26 in Official Methods of Analysis. 16th ed. Vol. 2. AOAC International, Arlington, VA.

Bauman, D. E., and W. B. Currie. 1980. Partitioning of nutrients during pregnancy and lactation: A review mechanisms involving homeostasis and homeorhesis. J. Dairy Sci. 63:1514-1529. https:// doi.org/10.3168/jds.S0022-0302(80)83111-0.

Baumgard, L. H., R. J. Collier, and D. E. Bauman. 2017. A 100-year review: Regulation of nutrient partitioning to support lactation. J. Dairy Sci. 100:10353-10366. https://doi.org/10.3168/jds.2017 -13242 .

Baumgard, L. H., G. J. Hausman, and M. V. Sanz Fernandez. 2016. Insulin: Pancreatic secretion and adipocyte regulation. Domest. Anim. Endocrinol. 54:76-84. https://doi.org/10.1016/j.domaniend 2015.07.001.

Baumgard, L. H., and R. P. Rhoads. 2012. Ruminant production and metabolic responses to heat stress. J. Anim. Sci. 90:1855-1865. https://doi.org/10.2527/jas.2011-4675.

Baumgard, L. H., and R. P. Rhoads Jr.. 2013. Effects of heat stress on postabsorptive metabolism and energetics. Annu. Rev. Anim. Biosci. 1:311-337. https://doi.org/10.1146/annurev-animal-031412 -103644 .

Baumgard, L. H., J. B. Wheelock, S. R. Sanders, C. E. Moore, H. B. Green, M. R. Waldron, and R. P. Rhoads. 2011. Postabsorptive carbohydrate adaptations to heat stress and monensin supplementation in lactating Holstein cows. J. Dairy Sci. 94:5620-5633. https://doi.org/10.3168/jds.2011-4462.

Bouraoui, R., M. Lahmar, A. Majdoub, M. Djemali, and R. Belyea. 2002. The relationship of temperature-humidity index with milk production of dairy cows in a Mediterranean climate. Anim. Res. 51:479-491. https://doi.org/10.1051/animres:2002036.
Collier, R. J., D. K. Beede, W. W. Thatcher, L. A. Israel, and C. J. Wilcox. 1982. Influences of environment and its modification on dairy animal health and production. J. Dairy Sci. 65:2213-2227. https://doi.org/10.3168/jds.S0022-0302(82)82484-3.

Collin, A., J. van Milgen, S. Dubois, and J. Noblet. 2001. Effect of high temperature on feeding behaviour and heat production in group-housed young pigs. Br. J. Nutr. 86:63-70.

Conte, G., R. Ciampolini, M. Cassandro, E. Lasagna, L. Calamari, U. Bernabucci, and F. Abeni. 2018. Feeding and nutrition management of heat stressed dairy ruminants. Ital. Anim. Sci. 17:604-620. https://doi.org/10.1080/1828051X.2017.1404944.

Cowley, F. C., D. G. Barber, A. V. Houlihan, and D. P. Poppi. 2015. Immediate and residual effects of heat stress and restricted intake on milk protein and casein composition and energy metabolism. J. Dairy Sci. 98:2356-2368. https://doi.org/10.3168/jds.2014-8442.

Das, R., L. Sailo, N. Verma, P. Bharti, J. Saikia, Imtiwati, and R. Kumar. 2016. Impact of heat stress on health and performance of dairy animals: A review. Vet. World 9:260-268. https://doi.org/10 .14202/vetworld.2016.260-268.

Fuquay, J. W. 1981. Heat stress as it affects production. J. Anim. Sci. 52:164-174. https://doi.org/10.2527/jas1981.521164x.

Gangloff, E. J., K. G. Holden, R. S. Telemeco, L. H. Baumgard, and A. M. Bronikowski. 2016. Hormonal and metabolic responses to upper temperature extremes in divergent life-history ecotypes of a garter snake. J. Exp. Biol. 219:2944-2954. https://doi.org/10 $.1242 /$ jeb. 143107.

Gao, S. T., J. Guo, S. Y. Quan, X. M. Nan, M. V. Sanz Fernandez, L. H. Baumgard, and D. Bu. 2017. The effects of heat stress on protein metabolism in lactating Holstein cows. J. Dairy Sci. 100:5040-5049. https://doi.org/10.3168/jds.2016-11913.

Geraert, P. A., J. C. F. Padilha, and S. Guillaumin. 1996. Metabolic and endocrine changes induced by chronic heat exposure in broiler chickens: Growth performance, body composition, and energy retention. Br. J. Nutr. 75:195-204. https://doi.org/10.1079/ BJN19960124.

Hays, W. P. 1926. The effect of environmental temperature on the percentage of fat in cow's milk. J. Dairy Sci. 9:219-235. https:// doi.org/10.3168/jds.S0022-0302(26)93890-3.

Huber, J. T. 1996. Amelioration of heat stress in dairy cattle. Pages 211-243 in Progress in Dairy Science. C. J. C. Philips, ed. CAB International, Wallingford, UK.

Itoh, F., Y. Obara, M. T. Rose, H. Fuse, and H. Hashimoto. 1998. Insulin and glucagon secretion in lactating cows during heat exposure. J. Anim. Sci. 76:2182-2189. https://doi.org/10.2527/1998 $.7682182 \mathrm{x}$

Kadzere, C. T., M. R. Murphy, N. Silanikove, and E. Maltz. 2002. Heat stress in lactating dairy cows: a review. Livest. Prod. Sci. 77:59-91. https://doi.org/10.1016/S0301-6226(01)00330-X.

Key, N., and S. Sneeringer. 2014. Potential effects of climate change on the productivity of U.S dairies. Am. J. Agric. Econ. 96:1136-1156. https://doi.org/10.1093/ajae/aau002.

Koch, F., U. Thom, E. Albrecht, R. Weikard, W. Nolte, B. Kuhla, and C. Kuehn. 2019. Heat stress directly impairs gut integrity and recruits distinct immune cell populations into the bovine intestine. Proc. Natl. Acad. Sci. USA 116:10333-10338. https://doi.org/10 .1073/pnas.1820130116.

Kvidera, S. K., E. A. Horst, M. Abuajamieh, E. J. Mayorga, M. V. Sanz Fernandez, and L. H. Baumgard. 2017. Glucose requirements of an activated immune system in lactating Holstein cows. J. Dairy Sci. 100:2360-2374. https://doi.org/10.3168/jds.2016-12001.

Lambert, G. P. 2009. Stress-induced gastrointestinal barrier dysfunction and its inflammatory effects. J. Anim. Sci. 87(Suppl_14):E101E108. https://doi.org/10.2527/jas.2008-1339.

Mayorga, E. J., S. K. Kvidera, E. A. Horst, M. Al-Qaisi, M. J. Dickson, J. T. Seibert, S. Lei, A. F. Keating, J. W. Ross, R. P. Rhoads, Z. J. Rambo, M. E. Wilson, and L. H. Baumgard. 2018. Effects of zinc amino acid complex on biomarkers of gut integrity and metabolism during and following heat stress or feed restriction in pigs. J. Anim. Sci. 96:4173-4185. https://doi.org/10.1093/jas/ sky 293. 
Michel, V., A. Peinnequin, A. Alonso, A. Buguet, R. Cespuglio, and F. Canini. 2007. Decreased heat tolerance is associated with hypothalamo-pituitary-adrenocortical axis impairment. Neuroscience 147:522-531. https://doi.org/10.1016/j.neuroscience.2007.04.035.

Nardone, A., N. Lacetera, U. Bernabucci, and B. Ronchi. 1997. Composition of colostrum from dairy heifers exposed to high air temperatures during late pregnancy and the early postpartum period. J. Dairy Sci. 80:838-844. https://doi.org/10.3168/jds.S0022 -0302(97)76005-3.

NRC. 2001. Nutrient Requirements of Dairy Cattle.7th rev. ed. Nat. Acad. Press, Washington, DC.

O'Brien, M. D., R. P. Rhoads, S. R. Sanders, G. C. Duff, and L. H. Baumgard. 2010. Metabolic adaptations to heat stress in growing cattle. Domest. Anim. Endocrinol. 38:86-94. https://doi.org/10 .1016/j.domaniend.2009.08.005.

Pearce, S. C., N. K. Gabler, J. W. Ross, J. Escobar, J. F. Patience, R. P. Rhoads, and L. H. Baumgard. 2013. The effects of heat stress and reduced plane of nutrition on metabolism in growing pigs. J. Anim. Sci. 91:2108-2118. https://doi.org/10.2527/jas.2012-5738.

Regan, W. M., and G. A. Richardson. 1938. Reactions of the dairy cow to changes in environmental temperature. J. Dairy Sci. 21:73-79. https://doi.org/10.3168/jds.S0022-0302(38)95617-6.

Rhoads, M. L., R. P. Rhoads, M. J. VanBaale, R. J. Collier, S. R. Sanders, W. J. Weber, B. A. Crooker, and L. H. Baumgard. 2009. Effects of heat stress and plane of nutrition on lactating Holstein cows: I. Production, metabolism, and aspects of circulating somatotropin. J. Dairy Sci. 92:1986-1997. https://doi.org/10.3168/ jds.2008-1641.

Sano, H., K. Takahashi, K. Ambo, and T. Tsuda. 1983. Turnover and oxidation rates of blood glucose and heat production in sheep exposed to heat. J. Dairy Sci. 66:856-861. https://doi.org/10.3168/ jds.S0022-0302(83)81867-0.
Sanz Fernandez, M. V., J. S. Johnson, M. Abuajamieh, S. K. Stoakes, J. T. Seibert, L. Cox, S. Kahl, T. H. Elsasser, J. W. Ross, S. C. Isom, R. P. Rhoads, and L. H. Baumgard. 2015. Effects of heat stress on carbohydrate and lipid metabolism in growing pigs. Physiol. Rep. 3:e12315. https://doi.org/10.14814/phy2.12315.

Sanz Fernandez, M. V., S. C. Pearce, N. K. Gabler, J. F. Patience, M. E. Wilson, M. T. Socha, J. L. Torrison, R. P. Rhoads, and L. H. Baumgard. 2014. Effects of supplemental zinc amino acid complex on gut integrity in heat-stressed growing pigs. Animal 8:43-50. https://doi.org/10.1017/S1751731113001961.

Schneider, P. L., D. K. Beede, C. J. Wilcox, and R. J. Collier. 1984. Influence of dietary sodium and potassium bicarbonate and total potassium on heat-stressed lactating dairy cows. J. Dairy Sci. 67:2546-2553. https://doi.org/10.3168/jds.S0022-0302(84)81611 -2 .

Shwartz, G., M. L. Rhoads, M. J. VanBaale, R. P. Rhoads, and L. H. Baumgard. 2009. Effects of a supplemental yeast culture on heatstressed lactating Holstein cows. J. Dairy Sci. 92:935-942. https:/ /doi.org/10.3168/jds.2008-1496.

West, J. W. 2003. Effects of heat stress on production in dairy cattle. J. Dairy Sci. 86:2131-2144. https://doi.org/10.3168/jds.S0022 -0302(03)73803-X.

West, J. W., G. Mullinix, and T. G. Sandifer. 1991. Effects of bovine somatotropin on physiologic responses of lactating Holstein and Jersey cows during hot, humid weather. J. Dairy Sci. 74:840-851. https://doi.org/10.3168/jds.S0022-0302(91)78233-7.

Wheelock, J. B., R. P. Rhoads, M. J. VanBaale, S. R. Sanders, and L. H. Baumgard. 2010. Effects of heat stress on energetic metabolism in lactating Holstein cows. J. Dairy Sci. 93:644-655. https://doi $.0 r g / 10.3168 /$ jds.2009-2295. 